Sains Malaysiana 50(8)(2021): 2219-2228

http://doi.org/10.17576/jsm-2021-5008-07

\title{
Different Maturities and Varieties of Coconut (Cocos nucifera L.) Flesh as Fat Replacers in Reduced-Fat Meatballs
}

(Perbezaan Tahap Kematangan dan Jenis Isi Kelapa (Cocos nucifera L.) sebagai Pengganti Lemak dalam Bebola Daging Rendah Lemak)

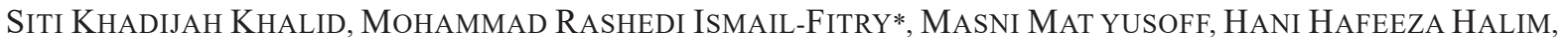 \\ AHMAD HANIFF JAAFAR \& NUR IZZAH ARIFAH ZARUL ANUAR
}

\begin{abstract}
Meatball is a popular meat product in Malaysia but it has high-fat content that could often bring health problems such as non-communicable diseases. This study aimed to produce replaced-fat meatballs using coconut flesh with three different varieties (i.e. MAWA, MYD, and Pandan) at two levels of maturities (young and matured). Meatballs with animal fat were used as control. All samples were analysed for the proximate composition, cooking yield, water holding capacity (WHC), texture and sensory properties. Two-way ANOVA was conducted to determine the interaction between the maturity and variety of the coconut for all parameters with post-hoc analysis to observe the significant difference $(p<0.05)$. The maturity and variety of coconuts showed significant interactions $(p<0.05)$ in affecting most of the meatball properties. Young coconuts were superior to mature coconut with better cooking yield $(p<0.05)$, texture and sensory properties. Meatballs with young Pandan had the highest moisture content $(p<0.05)(71.78 \%)$, low fat $(3.56 \%)(p<0.05)$, and overall sensory acceptance. Meatballs with young MYD had low fat content (3.50\%) $(p<0.05)$, high WHC (52.11) (p<0.05), high redness (6.09) ( $p<0.05)$ with a high score of the colour (7.13) taste (7.17), texture (7.30) and overall acceptability (7.03) for the sensory properties. Since both young Pandan and young MYD managed to reduce the fat content in the meatballs as compared to the control sample and other treatments while maintaining the quality characteristics of the meatballs, both can be concluded to have potential as the fat replacers in the production of reduced-fat meatballs.
\end{abstract}

Keywords: Coconut flesh; fat replacer; low-fat meatballs; mature coconut; young coconut

ABSTRAK

Bebola daging adalah produk daging yang popular di Malaysia tetapi ia mempunyai kandungan lemak yang tinggi dan boleh membawa masalah kesihatan seperti penyakit tidak berjangkit. Kajian ini bertujuan untuk menghasilkan bebola daging dengan lemak gantian berasaskan tiga jenis isi kelapa yang berbeza (iaitu MAWA, MYD dan Pandan) pada dua tahap kematangan (muda dan matang). Bebola daging dengan lemak haiwan digunakan sebagai sampel kawalan. Semua sampel dianalisis untuk komposisi proksimat, hasil memasak, daya tahan air (WHC), sifat tekstur dan deria. ANOVA dua hala dijalankan untuk menentukan interaksi antara kematangan dan kepelbagaian jenis kelapa untuk semua parameter dengan analisis post-hoc untuk menilai perbezaan yang signifikan $(p<0.05)$. Kematangan dan jenis kelapa menunjukkan interaksi yang signifikan $(p<0.05)$ dalam mempengaruhi sebilangan besar sifat bebola daging. Kelapa muda adalah lebih baik daripada kelapa matang dengan keputusan yang lebih baik untuk hasil memasak ( $<<0.05)$, sifat tekstur dan deria. Bebola daging dengan kelapa Pandan muda mempunyai kandungan kelembapan tertinggi $(p<0.05)$ $(71.78 \%)$, rendah lemak (3.56\%) ( $<<0.05)$, dan penerimaan deria secara keseluruhan yang baik. Bebola daging dengan kelapa MYD muda mempunyai kandungan lemak yang rendah (3.50\%) ( $p<0.05)$, daya tahan air yang tinggi (52.11) $(p<0.05)$, warna merah yang tinggi (6.09) ( $<<0.05)$ dengan skor yang tinggi untuk warna (7.13) rasa (7.17), tekstur (7.30) dan penerimaan keseluruhan (7.03) untuk penilaian sifat deria. Oleh kerana kedua-dua kelapa Pandan muda 
dan MYD muda berjaya mengurangkan kandungan lemak dalam bebola berbanding dengan sampel kawalan dan sampel yang lain di samping mengekalkan ciri-ciri kualiti bebola daging, kedua-duanya dapat disimpulkan berpotensi sebagai pengganti lemak dalam penghasilan bebola daging rendah lemak.

Kata kunci: Bebola daging rendah lemak; isi kelapa; kelapa matang; kelapa muda; pengganti lemak

\section{INTRODUCTION}

Meat emulsion-based products such as meatballs are commonly made up of meat protein, animal fat and water with added non-meat ingredients such as salt, phosphates, flour and spices. The animal fat highly contributes to the quality of meatball, especially its organoleptic attributes, such as flavour, texture, juiciness and binding properties, that can greatly affect the eating quality of the meat product (Huang et al. 2005; Yilmaz \& Dağlıŏlu 2003). However, animal fat is linked with non-communicable diseases, such as coronary heart disease and obesity (Aslinah et al. 2018). In the market, the demand towards reducedfat meat products is growing among health-conscious consumers, and the use of fat replacer is one of the alternatives in developing such products. Fat replacers can be categorized based on their composition, which is lipid-, carbohydrate- or protein-based in which each possesses different functional properties with respective pros and cons in their applications (Akbari et al. 2019).

The use of different sources of materials mostly from the plant as the fat replacer and ensuring palatability required by consumers within the same time is not an easy task. Fat replacer ingredients must act as either to replace the fat or to change the remaining components' interactions (Jalal et al. 2013). Plant materials such as oat bran (Yilmaz \& Dağlıoğlu 2003), rye bran (Yilmaz 2004), ground poppy seed (Gok et al. 2011), washed cashew apple fibre (Guedes-Oliveira et al. 2016), adzuki beans flour (Aslinah et al. 2018), artichoke powder (Ozturk \& Serdaroglu 2018), and black bean coats (Niu et al. 2020) have been reported as potential fat replacers. Several notable issues related to replacing the animal fat with the non-meat components are associated with the reduction of moisture, cooking yield and water holding capacity, undesirable colour and texture development, and unacceptable sensory characteristics.

In Malaysia, coconut is the fourth most important crops along with oil palm, rubber and paddy based on the total planted area (Mohamad Ja et al. 2019). Coconut
(Cocos nucifera $\mathrm{L}$.) flesh is nutritious with vitamin $\mathrm{E}$ and polyunsaturated fatty acid whilst exhibiting low cholesterol level compared to animal fat, therefore, it has potentials to be used as the fat replacer for a healthier meat product (Chuntarat et al. 2013; Imo et al. 2018; Onsaard et al. 2006). In addition, it has an aromatic flavour and odour (Jangchud et al. 2007) which could beneficially affect the sensory acceptance of the final product. Fresh coconut flesh also was reported to have an excellent emulsifying property of protein which might be suitable to be incorporated into meat products (Onsaard et al. 2006). However, different maturity and variety of coconut could produce different quality characteristics of the meat products. Coconut flesh contains a high amount of carbohydrates and nutrient content at different maturity stages (6-9 months) with $45.7-52.5 \%$ fat, $3.6-4.5 \%$ protein, and $2.5-3.0 \%$ ash was recorded. Meanwhile, the moisture content and total carbohydrate were significantly different along with the maturation. The young coconut flesh had been reported to contain the highest moisture (Chuntarat et al. 2013). This finding was similar to the study done by Solangi and Iqbal (2011) which reported significant different moisture content in coconuts of different varieties. Therefore, this work aimed to incorporate coconut flesh (Cocos nucifera L.) of different varieties and maturities as fat replacers in production of reduced-fat meatballs.

\section{MATERIALS AND METHODS}

\section{PREPARATION OF COCONUT FLESH}

Three coconut varieties namely hybrid Malayan Yellow Dwarf $\times$ West African Tall (MAWA), Malayan Yellow Dwarf (MYD) and aromatic dwarf (Pandan) from two different maturity levels (young and mature) were harvested from the Malaysian Agricultural Research and Development Institute (MARDI) Bagan Datuk Station, Perak. The selection of the young and mature coconuts was based on the bunch number of coconuts on the trees and the flesh thickness measured after harvested. The 
soft flesh is considered as young while the hard flesh is categorized as the mature coconut (Halim et al. 2018). Each coconut sample was cut into two and the flesh was rinsed with water. Then, the flesh was scooped out from the shell and grounded to reduce the size. The flesh of the mature coconut was first grated before grounded.

\section{MEATBALLS PROCESSING}

The meatballs processing was carried out based on the method by Aslinah et al. (2018). The chuck part of buffalo meat and the fat used were obtained from Shahrul Frozen, Cheras, Selangor. Sodium tripolyphosphate (STPP) was supplied by Meilun Food Chemical Sdn Bhd, Klang, Selangor, while, other ingredients were purchased from Giant Hypermarket, Seri Kembangan, Selangor. The semi-frozen meats and fat were minced by using meat mincer (HOBART 4822, Germany) separately, followed by storage in a freezer $\left(-18^{\circ} \mathrm{C}\right)$ to control the temperature prior to the meatball processing. Upon thawing, $74 \%$ of the minced meat was mixed with $10 \%$ fat, $8.7 \%$ ice water, $4.2 \%$ corn flour, $1.2 \%$ salt, $0.7 \%$ onion powder, $0.6 \%$ sugar, $0.5 \%$ STPP and $0.1 \%$ monosodium glutamate (by weight) to produce the control meatballs. For the reducedfat meatballs, the fat was replaced either by young MAWA, young MYD, young Pandan, mature MAWA, mature MYD or mature Pandan. All the ingredients were mixed for $15 \mathrm{~min}$ in a bowl cutter (Mainca CM-41S, Spain) until homogenized. Then, salt and STPP were added followed by ice water to control the temperature. The round meatballs were formed manually with a weight of $10 \pm 0.5 \mathrm{~g}$ each and were in warm water $\left(45^{\circ} \mathrm{C}\right)$ for $20 \mathrm{~min}$ to set. The set meatballs were further placed in hot water of approximately $90^{\circ} \mathrm{C}$ for $20 \mathrm{~min}$. Then, the excessive water was drained out and the meatballs were left to cool at room temperature followed by storage in a freezer $\left(-18^{\circ} \mathrm{C}\right)$ until further analysis. Three replications of each formulation were prepared.

\section{PROXIMATE ANALYSIS}

Proximate composition of meatball formulations comprising of moisture, protein, fat, and ash content was determined following the standard methods from the Association of Official Analytical Chemists (Association of Officiating Analytical Chemists 2005). The methods used for the analyses were: moisture content, oven drying method; protein content, Micro Kjeldahl method; fat content, Soxhlet method; ash content, dry method; and carbohydrate content, by calculation.

\section{ESTIMATION OF COOKING YIELD}

The cooking yield was measured by calculating the difference of the sample weight $(\mathrm{g})$ before and after cooking (Aslinah et al. 2018) and was calculated using the following formula:

Cooking yield $(\%)=($ Weight of cooked meatballs $/$ Weight of uncooked meatballs $) \times 100$

\section{WATER HOLDING CAPACITY}

Water holding capacity (WHC) represents the percentage of bound water in meatballs and was determined in accord with the method described by Skipnes et al. (2007). $5 \mathrm{~g}$ of cooked meatballs and $10 \mathrm{~mL}$ of distilled water was placed in $50 \mathrm{~mL}$ centrifuge tube, followed by centrifugation for $15 \mathrm{~min}$ at $1500 \mathrm{rpm}$. The WHC of the samples was calculated using the following formula:

$\% \mathrm{WHC}=($ Initial water content in the sample - final water content in the sample) / Weight of sample $\times 100$

\section{COLOUR ANALYSIS}

Colour properties of the meatballs were determined by a Chroma meter (CR-410 Konica Minolta, Japan) and were reported in terms of lightness $\left(L^{*}\right)$, redness $\left(a^{*}\right.$, \pm red-green) and yellowness $\left(b^{*}, \pm\right.$ yellow-blue) (Ikhlas et al. 2011).

\section{TEXTURE PROFILE ANALYSIS}

The textural properties of the meatballs were determined in terms of springiness, chewiness, hardness, gumminess, and cohesiveness by using a TA-XT2 texture analyser (Stable Microsystem System LTD, United Kingdom) aided with software 'Texture Expert'. The procedures to operate Texture Analyser were following the Standard Operating Procedure (SOP) where it was performed with a compression platen of $75 \mathrm{~mm}$ in diameter. The TA-XT2 setting in TPA test was set to be as followed: load cell = $25 \mathrm{~kg}$, pre-test speed $=2.0 \mathrm{~mm} \mathrm{~s}^{-1}$, test speed $=5.0 \mathrm{~mm}$ $\mathrm{s}^{-1}$, post-test speed $=5.0 \mathrm{~mm} \mathrm{~s}^{-1}$ and trigger type $=$ Auto and strain $=50 \%$.

\section{SENSORY EVALUATION}

The sensory test was carried out in determining the degree of acceptance of the meatball samples in terms of texture, colour, odour, taste, flavour and in overall. The nine-point 
hedonic scale (1-dislike extremely to 9-like extremely) was used, and 30 untrained panellists were involved. The meatball samples were labelled using random three-digit numbers and were presented to the panellists in a random permutation.

\section{STATISTICAL ANALYSIS}

The data analysis was carried out by using Minitab 17 Statistical Software (Minitab Inc., State College, PA). Two-way ANOVA was performed to study the effect of maturity and variety factors and also the interaction between maturity and variety towards the analyses. The post-hoc analysis was performed by the Tukey test. Pearson correlation was used to analyze the correlations between the data. All data were presented as mean \pm standard deviation with $\mathrm{p}<0.05$ is considered as significantly different.

\section{RESULTS AND DISCUSSION \\ PROXIMATE COMPOSITION}

The proximate compositions of the meatballs are shown in Table 1. In all fat-replaced meatballs incorporated with coconut flesh, the maturity and variety of the coconuts exhibited significant interaction effects $(p<0.05)$ towards these properties except for the protein content $(p>0.05)$. As compared to animal fat (control sample) and other coconut varieties, the use of Pandan coconut flesh as fat replacer resulted in significantly highest $(\mathrm{p}<0.05)$ moisture content of $71.78 \%$ (young) and $64.08 \%$ (mature) in the meatballs. Meanwhile, the meatballs with mature MYD, mature MAWA and young MYD exhibited significantly lowest $(p<0.05)$ moisture content. Furthermore, all meatballs incorporated with coconut flesh had lower $(\mathrm{p}<0.05)$ ash content $(0.51-1.25 \%)$ as compared to the control sample $(2.38 \%)$, while there was no difference ( $p>0.05)$ between all meatballs in terms of protein content. The fat content in meatballs incorporated with young Pandan $(3.56 \%)$ and young MYD $(3.50 \%)$ was the lowest $(\mathrm{P}<0.05)$ as compared to those of other coconut flesh $(7.19-7.80 \%)$ and the control $(9.41 \%)$ sample. The young MYD flesh also contributed to the highest $(\mathrm{p}<0.05)$ carbohydrate content (16.91\%) in the meatball, while the use of both young (7.97\%) and mature (7.95\%) Pandan flesh resulted in meatballs with the lowest $(p<0.05)$ carbohydrate content.

TABLE 1. Proximate composition, cooking yield, water holding capacity and colour of the fat-replaced meatballs with different maturity and variety of coconut

\begin{tabular}{|c|c|c|c|c|c|c|c|c|c|c|}
\hline & \multicolumn{3}{|c|}{ 2-way ANOVA } & \multirow[b]{2}{*}{ Control } & \multicolumn{3}{|c|}{ Young } & \multicolumn{3}{|c|}{ Mature } \\
\hline & Maturity & Variety & $\begin{array}{l}\text { Maturity } \\
\times \text { Variety }\end{array}$ & & MAWA & MYD & Pandan & MAWA & MYD & Pandan \\
\hline \multicolumn{11}{|l|}{$\begin{array}{l}\text { Proximate } \\
\text { composition }\end{array}$} \\
\hline Moisture (\%) & $<0.001$ & $<0.001$ & $<0.001$ & $64.56 \pm 0.26^{\mathrm{c}}$ & $64.60 \pm 0.32^{\mathrm{c}}$ & $63.37 \pm 0.19^{d}$ & $71.78 \pm 0.46^{\mathrm{a}}$ & $63.33 \pm 0.33^{\mathrm{d}}$ & $62.51 \pm 0.34^{\mathrm{d}}$ & $68.04 \pm 0.26^{\mathrm{b}}$ \\
\hline Ash (\%) & $<0.001$ & $<0.001$ & $<0.001$ & $2.38 \pm 0.11^{\mathrm{a}}$ & $1.08 \pm 0.12^{\mathrm{b}}$ & $1.22 \pm 0.01^{\mathrm{b}}$ & $1.16 \pm 0.02^{\mathrm{b}}$ & $0.51 \pm 0.08^{\mathrm{c}}$ & $0.60 \pm 0.02^{\mathrm{c}}$ & $1.25 \pm 0.03^{\mathrm{b}}$ \\
\hline Protein (\%) & $\mathrm{ns}$ & $\mathrm{ns}$ & $\mathrm{ns}$ & $15.77 \pm 0.35$ & $14.95 \pm 0.18$ & $15.01 \pm 0.36$ & $15.52 \pm 0.81$ & $15.71 \pm 0.20$ & $15.41 \pm 0.47$ & $15.58 \pm 0.47$ \\
\hline Fat $(\%)$ & $<0.001$ & $<0.001$ & $<0.001$ & $9.41 \pm 0.25^{\mathrm{a}}$ & $7.53 \pm 0.12^{b}$ & $3.50 \pm 0.18^{c}$ & $3.56 \pm 0.18^{\mathrm{c}}$ & $7.80 \pm 0.22^{\mathrm{b}}$ & $7.50 \pm 0.42^{\mathrm{b}}$ & $7.19 \pm 0.31^{b}$ \\
\hline $\begin{array}{l}\text { Carbohydrate } \\
(\%)\end{array}$ & 0.015 & $<0.001$ & $<0.001$ & $7.88 \pm 0.60^{\mathrm{d}}$ & $11.83 \pm 0.55^{\mathrm{c}}$ & $16.91 \pm 0.33^{\mathrm{a}}$ & $7.97 \pm 0.78^{\mathrm{d}}$ & $12.66 \pm 0.18^{\mathrm{bc}}$ & $13.76 \pm 0.79^{\mathrm{b}}$ & $7.95 \pm 0.64^{\mathrm{d}}$ \\
\hline $\begin{array}{l}\text { Cooking yield } \\
(\%)\end{array}$ & $<0.001$ & $<0.001$ & $<0.001$ & $97.27 \pm 0.30^{\mathrm{a}}$ & $97.00 \pm 0.25^{\mathrm{a}}$ & $97.45 \pm 0.75^{\mathrm{a}}$ & $97.80 \pm 0.28^{\mathrm{a}}$ & $93.61 \pm 0.32^{\mathrm{b}}$ & $89.68 \pm 0.41^{\mathrm{c}}$ & $94.77 \pm 0.51^{\mathrm{b}}$ \\
\hline $\begin{array}{l}\text { Water Holding } \\
\text { Capacity }(\%)\end{array}$ & $<0.001$ & $<0.001$ & $<0.001$ & $37.05 \pm 0.98^{c}$ & $17.98 \pm 0.48^{\mathrm{f}}$ & $52.11 \pm 0.63^{\mathrm{a}}$ & $30.18 \pm 0.81^{\mathrm{e}}$ & $34.10 \pm 0.77^{d}$ & $45.25 \pm 0.19^{\mathrm{b}}$ & $46.96 \pm 0.92^{\mathrm{b}}$ \\
\hline \multicolumn{11}{|l|}{ Colour } \\
\hline$L^{*}$ & $\mathrm{~ns}$ & $<0.001$ & $<0.001$ & $55.52 \pm 0.39^{\mathrm{d}}$ & $57.57 \pm 0.12^{\mathrm{a}}$ & $52.82 \pm 0.53^{\mathrm{f}}$ & $56.45 \pm 0.20^{\mathrm{bc}}$ & $55.70 \pm 0.31^{\mathrm{cd}}$ & $54.47 \pm 0.31^{\mathrm{e}}$ & $56.68 \pm 0.31^{\mathrm{ab}}$ \\
\hline$a^{*}$ & ns & ns & $<0.001$ & $4.73 \pm 0.10^{\text {cd }}$ & $5.25 \pm 0.17^{\mathrm{abc}}$ & $6.09 \pm 0.26^{\mathrm{a}}$ & $4.08 \pm 0.49^{\mathrm{d}}$ & $5.15 \pm 0.21^{\mathrm{bc}}$ & $4.55 \pm 0.40^{\text {cd }}$ & $5.78 \pm 0.39^{\mathrm{ab}}$ \\
\hline$b^{*}$ & ns & ns & ns & $10.69 \pm 0.30$ & $9.88 \pm 0.05$ & $9.59 \pm 0.26$ & $9.69 \pm 0.70$ & $10.27 \pm 0.44$ & $9.42 \pm 0.28$ & $10.11 \pm 0.43$ \\
\hline
\end{tabular}

If interaction of factors is present, the post-hoc groupings is only for the interaction effects which indicated by lowercase letters; different letters are significantly 
Overall, the proximate composition (except protein content) of the fat-replaced meatballs was significantly affected by the different varieties and maturities of the coconut flesh used. Maturity of the coconut could influence the moisture content of the flesh. Young coconut flesh, which is like layers of jelly was reported to have a higher moisture content as compared to mature coconut flesh (Appaiah et al. 2015; Terdwongworakul et al. 2009). However, Solangi and Iqbal (2011) reported otherwise with higher moisture content in the mature coconuts. These contrast findings were mainly due to the different varieties of the coconuts which exhibit different moisture content. The interaction effect $(\mathrm{p}<0.05)$ between maturity and variety of the coconuts can therefore be observed. On the other hand, coconut flesh was reported to exhibit low ash content between $0.81-1.28 \%$ at different maturity and variety (Nnorom et al. 2013; Solangi \& Iqbal 2011), which again reflected the ash contents in the fat-replaced meatballs. Young coconut flesh had lower fat content as compared to the mature coconut (Appaiah et al. 2015), therefore, supported the results obtained for the meatballs with young MYD and young Pandan.

The fat and moisture contents are closely related to meat products, and if the fat content is low, the moisture content is likely to be high. According to Grigelmo-Migue et al. (1999), the high-water content in meat products can be associated with the presence of fruit fibre. If there is no addition of binder into the meatballs, fat will be separated excessively within the matrix of meat protein (Serdaroglu 2006). The elevation of fat content stimulates the decrement of the free distance between droplets of fat; therefore, those fat droplets join together and subsequently leach out along the cooking process (Serdaroglu \& Degirmencioglu 2004). According to Malaysian Food Regulations 1985, meat products should consist of less than $3 \%$ fat to be categorized as low-fat. Despite that, the sensory acceptance result should also be considered due to consumer's preference where people choose to buy products not only good for their health but also have acceptable and palatable taste (Aslinah et al. 2018). As the young Pandan flesh improved the moisture content and reduced the fat content of the meatballs, young MYD also decreased the fat content yet increased the carbohydrate content at the same time. Having higher carbohydrates is also advantageous in meat products as it could elevate the water-holding capacity, improve cooking yield, affect end product texture, produce better stability of freezing thaw and decrease production cost (Huda et al. 2010).

\section{COOKING YIELD, WATER HOLDING CAPACITY AND COLOUR}

The maturity and variety of the coconut's flesh used showed significant interaction effect $(p<0.05)$ towards both the cooking yield and water-holding capacity (WHC) of the fat-replaced meatballs (Table 1). The cooking yield of the meatballs incorporated with young coconut fleshes (97.00-97.80\%) as fat replacer was insignificantly difference $(p>0.05)$ against the control sample $(97.27 \%)$, but was higher $(\mathrm{p}<0.05)$ as compared to the flesh of the mature coconut (89.68-94.77\%). The WHC of meatballs with young MYD flesh $(52.11 \%)$ as fat replacer was the highest $(\mathrm{p}<0.05)$, followed by mature Pandan (46.96\%) and mature MYD (45.25\%). Serdaroglu and Degirmencioglu (2004) claimed that low cooking yield can result from moisture and fat loss and the denaturation of the meat proteins. The factors affecting the cooking yield of meat products depends on the amount of fat in the products (Hughes et al. 1998), cooking temperature (Kim \& Chin 2007), cooking time (Banon et al. 2008) and the ingredients (Huang et al. 2005).

The ability of meat products to retain moisture during cooking and processing is an important characteristic that significantly influences the quality and yield of the end product (Luckose \& Pandey 2014). The coconut flesh is capable to hold water, hence thwarting excessive moisture loss from the meatballs which is a favourable implication to the final product quality; whereas, poor WHC may result in an undesirable texture (Ergezer et al. 2014; Serdaroglu 2006). A more stable protein matrix produces smaller water- and fat-release, thus ameliorating binding properties of meat products (Pietrasik \& Shand 2003). The WHC of meatballs in this study (17.98-52.11\%) was comparable to the buffalo meat patties with squashes and gourds as fat replacers (28.01-36.81\%) (Kahar et al. 2021) but lower than potato meatballs with puree and bread crumbs as the fat replacers (0.64-0.72\%) (Ergezer et al. 2014).

The maturity and variety of the coconuts also had significant interaction effect $(\mathrm{p}<0.05)$ towards the lightness $\left(L^{*}\right)$ and redness $\left(a^{*}\right)$ of the meatballs with coconut flesh as a fat replacer, but not for the yellowness $\left(b^{*}\right)(\mathrm{p}>0.05)$ (Table 1). The replacement of fat with coconut flesh did increase the lightness $\left(L^{*}\right)$ of the meatballs $(\mathrm{p}<0.05)$ against the control (55.52) especially for young MAWA (57.57), young Pandan (56.45) and mature Pandan (56.68). However, meatballs incorporated with both young and mature MYD flesh (52.82 and 54.47, respectively) exhibited lower lightness $(\mathrm{p}<0.05)$ as compared to other 
meatballs. The changes in whiteness as indicated by the $L^{*}$ value might be due to the presence of white-coloured compounds in the coconut flesh (Fernandez-Gines et al. 2004). The redness values ( $\left.a^{*}\right)$ of meatballs with coconut flesh of mature Pandan (5.78) and young MYD (6.09) were higher than the control sample (4.73), whereas the redness of other samples was not significantly $(p>0.05)$ different from the control sample. The maturity and variety of the coconuts showed no significant interaction effect $(p>0.05)$ towards the yellowness $\left(b^{*}\right)$ intensity and the values were insignificantly different $(\mathrm{p}>0.05)$ between all meatballs. The similar $b^{*}$ values might be due to the presence of yellow compounds in coconut which might have masked the meat emulsion (Fernandez-Gines et al. 2004). The meatballs' colour depends highly on the fat content, besides the type of additives and flour used (Huda et al. 2010; Serdaroglu et al. 2005); therefore, differences observed could be due to the maturity and variety of the coconuts.

\section{TEXTURE PROPERTIES}

The maturity and variety of the coconut flesh showed significant interaction effect $(\mathrm{p}<0.05)$ towards the hardness, chewiness, and gumminess, but not the springiness and cohesiveness $(p>0.05)$ of the meatballs (Table 2). All meatballs showed no significant difference $(p>0.05)$ in terms of hardness except for those incorporated with mature MAWA which exhibited lower value $(\mathrm{P}<0.05)$ as compared to young MAWA, MYD and Pandan, and mature Pandan. Young MAWA also resulted in the lowest $(p<0.05)$ chewiness and gumminess in the meatballs as compared to young MAWA and mature Pandan, while other meatballs were insignificantly different $(\mathrm{p}>0.05)$. Only meatballs incorporated with mature MAWA and MYD as fat replacers showed significant difference $(p<0.05)$ in springiness as compared to the control sample. Whereas no difference $(p>0.05)$ was observed in terms of cohesiveness between all the meatballs.

TABLE 2. Texture and sensory properties of the fat-replaced meatballs with different maturity and variety of coconut

\begin{tabular}{|c|c|c|c|c|c|c|c|c|c|c|}
\hline & \multicolumn{3}{|c|}{ 2-way ANOVA } & \multirow[b]{2}{*}{ Control } & \multicolumn{3}{|c|}{ Young } & \multicolumn{3}{|c|}{ Mature } \\
\hline & Maturity & Variety & $\begin{array}{c}\text { Maturity } \\
\times \\
\text { Variety }\end{array}$ & & MAWA & MYD & Pandan & MAWA & MYD & Pandan \\
\hline \multicolumn{11}{|l|}{ Texture } \\
\hline $\begin{array}{l}\text { Springiness } \\
(\mathrm{mm})\end{array}$ & 0.008 & 0.040 & ns & $0.89 \pm 0.03^{\mathrm{Aa}}$ & $0.91 \pm 0.01^{\mathrm{Aa}}$ & $0.89 \pm 0.01^{\mathrm{Aa}}$ & $0.90 \pm 0.01^{\mathrm{Aa}}$ & $0.88 \pm 0.01^{\mathrm{Ba}}$ & $0.85 \pm 0.01^{\mathrm{Ba}}$ & $0.90 \pm 0.03^{\mathrm{Aa}}$ \\
\hline Hardness (N) & 0.004 & 0.047 & 0.026 & $65.06 \pm 5.32^{\mathrm{ab}}$ & $81.59 \pm 15.64^{\mathrm{a}}$ & $78.65 \pm 3.71^{\mathrm{a}}$ & $79.32 \pm 5.01^{\mathrm{a}}$ & $48.47 \pm 11.48^{b}$ & $60.39 \pm 10.08^{\mathrm{ab}}$ & $81.43 \pm 6.57^{\mathrm{a}}$ \\
\hline $\begin{array}{l}\text { Chewiness } \\
\text { (N.mm) }\end{array}$ & 0.009 & 0.050 & 0.024 & $40.49 \pm 5.31^{\mathrm{ab}}$ & $52.64 \pm 13.38^{\mathrm{a}}$ & $44.99 \pm 0.82^{\mathrm{ab}}$ & $48.67 \pm 2.45^{\mathrm{ab}}$ & $30.93 \pm 6.40^{\mathrm{b}}$ & $35.17 \pm 5.55^{\mathrm{ab}}$ & $51.31 \pm 2.28^{\mathrm{a}}$ \\
\hline Gumminess (N) & 0.016 & ns & 0.029 & $45.38 \pm 5.25^{\mathrm{ab}}$ & $57.68 \pm 13.61^{\mathrm{a}}$ & $50.42 \pm 0.88^{\mathrm{ab}}$ & $54.21 \pm 3.05^{\mathrm{ab}}$ & $35.28 \pm 7.24^{\mathrm{b}}$ & $41.59 \pm 6.29^{\mathrm{ab}}$ & $57.31 \pm 3.97^{\mathrm{a}}$ \\
\hline Cohesiveness & 0.041 & 0.034 & ns & $0.70 \pm 0.07^{\mathrm{Aa}}$ & $0.70 \pm 0.04^{\mathrm{Aa}}$ & $0.64 \pm 0.03^{\mathrm{Aa}}$ & $0.68 \pm 0.02^{\mathrm{Aa}}$ & $0.73 \pm 0.02^{\mathrm{Aa}}$ & $0.69 \pm 0.03^{\mathrm{Aa}}$ & $0.71 \pm 0.03^{\mathrm{Aa}}$ \\
\hline \multicolumn{11}{|l|}{ Sensory } \\
\hline Colour & $<0.001$ & ns & $<0.001$ & $6.53 \pm 1.31^{\mathrm{ab}}$ & $6.37 \pm 1.22^{\mathrm{abcd}}$ & $7.13 \pm 1.22^{\mathrm{a}}$ & $6.43 \pm 1.31^{\mathrm{abc}}$ & $5.47 \pm 1.28^{\mathrm{cd}}$ & $5.40 \pm 1.16^{\mathrm{d}}$ & $5.60 \pm 1.30^{\mathrm{bcd}}$ \\
\hline Aroma & $<0.001$ & 0.028 & $\mathrm{~ns}$ & $6.30 \pm 1.51^{\mathrm{Aa}}$ & $5.63 \pm 1.43^{\mathrm{ABa}}$ & $6.37 \pm 1.38^{\mathrm{Aa}}$ & $6.50 \pm 1.43^{\mathrm{Aa}}$ & $4.97 \pm 1.35^{\mathrm{Bb}}$ & $5.13 \pm 1.20^{\mathrm{Bb}}$ & $5.40 \pm 1.30^{\mathrm{Bab}}$ \\
\hline Taste & $<0.001$ & 0.002 & 0.001 & $6.20 \pm 1.71^{\mathrm{ab}}$ & $6.03 \pm 1.63^{\mathrm{ab}}$ & $7.17 \pm 1.44^{\mathrm{a}}$ & $6.70 \pm 1.24^{\mathrm{ab}}$ & $4.67 \pm 1.40^{\mathrm{c}}$ & $4.37 \pm 1.77^{\mathrm{c}}$ & $5.97 \pm 1.63^{\mathrm{b}}$ \\
\hline Texture & $<0.001$ & 0.025 & ns & $\begin{array}{c}6.43 \pm 1.61^{\mathrm{Aa}} \\
(\mathrm{AB})\end{array}$ & $6.53 \pm 1.53^{\mathrm{Aa}}$ & $7.30 \pm 1.09^{\mathrm{Aa}}$ & $7.17 \pm 1.12^{\mathrm{Aa}}$ & $5.20 \pm 1.67^{\mathrm{Bb}}$ & $5.10 \pm 1.75^{\mathrm{Bb}}$ & $6.07 \pm 1.68^{\mathrm{Bab}}$ \\
\hline $\begin{array}{l}\text { Overall } \\
\text { Acceptability }\end{array}$ & $<0.001$ & 0.001 & 0.005 & $6.23 \pm 1.75^{\mathrm{a}}$ & $6.07 \pm 1.69^{\mathrm{a}}$ & $7.03 \pm 1.66^{\mathrm{a}}$ & $6.77 \pm 1.59^{\mathrm{a}}$ & $4.77 \pm 1.45^{\mathrm{bc}}$ & $4.58 \pm 1.65^{\mathrm{c}}$ & $5.84 \pm 1.59^{\mathrm{ab}}$ \\
\hline
\end{tabular}

If interaction of factors is present, the post-hoc groupings is only for the interaction effects which indicated by lowercase letters; different letters are significantly different $(\mathrm{P}<0.05)$. If no interaction is present, the post-hoc analysis are for both individual maturity and variety factor: means that do not share the same uppercase lette in the same row are significantly different between the control, young and matured at the same varieties $(\mathrm{p}<0.05)$; means that do not share the same lowercase letter in the same row are significantly different between the control and different varieties of coconut flesh within the same maturity ( $\mathrm{p}<0.05)$. ${ }^{(\mathrm{AB})}$ showed comparison between the control, young and mature Pandan 
The textural profiles of meat-based products are highly contributed by stromal protein content, extracted protein, non-meat ingredient type and comminuting degree. For meatballs, the binders, starch and extenders play the major roles in affecting the hardness of products (Serdaroglu et al. 2005). Fat also particularly influences the texture of a meat product. When using plant-based materials to replace the animal fat, the emulsion produced could be affected, thus resulted in different texture properties. The coconut flesh consists of high dietary fibre (Trinidad et al. 2006) and oil (Savva \& Kafatos 2015) besides other components. Both the fibre and oil could interact with the myofibrillar proteins to form a stable emulsion. The mechanical force applied during the mixing could reduce the particle size of the coconut flesh. If the fat replacer globules are similar to the fat globules, it may be successfully incorporated into protein-starch-fat networks (Chen et al. 2019). Replacing the animal fat with other oils such as canola oil organogel (Alejandre et al. 2019) resulted in a softer texture, while study using high fibre plants such as oat bran (Yilmaz \& Dağlığlu 2003) increased the firmness in meat product. Therefore, coconut flesh which contains both fibre and oil could produce a balanced texture of meatballs.

\section{SENSORY PROPERTIES}

Significant interactions between maturity and variety of the coconut flesh were observed $(p<0.05)$ in affecting the sensory acceptance of the meatballs in terms of colour, taste and overall acceptability, but not the aroma and texture $(p>0.05)$ (Table 2). No significant difference $(p>0.05)$ was observed between all the meatballs incorporated with young coconut fleshes as the fat replacers against the control sample for all the sensory properties tested. For the colour and taste, young MYD particularly contributed to meatball with the highest acceptance score $(p<0.05)$ as compared to those incorporated with mature coconut fleshes. The high redness value (Table 1) of meatball with young MYD could be related to the high sensory acceptance score in terms of the colour as it reflected the meat colour. All meatballs incorporated with mature coconut flesh as a fat replacer had a lower score $(p<0.05)$ for all properties against the control sample, except for the overall acceptability of the mature Pandan $(p<0.05)$. There was no difference $(p>0.05)$ between the control sample and all the meatballs with young coconut fleshes as fat replacers in terms of both aroma and texture, while the use of mature coconuts showed otherwise with a lower preference for the meatballs $(p<0.05)$ except for the mature Pandan.
Young Pandan as fat replacer of the meatballs scored the highest aroma might be due to the preference of the majority of people who love the good smell of Pandan flesh which is like pandanus leaves (Jangchud et al. 2007). Higher scores for the aroma and taste of the young coconuts might be due to the sugar residues from coconut flesh, amino acids and small peptides from the meat caused by Maillard reaction upon heating, which gives the meat product a desirable taste (Bhosale et al. 2011). The MYD has also been reported to have a sweeter taste of coconut juice compared to Pandan and MAWA where the juice later develops the flesh in the fruits (Halim et al. 2018). The coconut flesh consists of salts such as sodium and chlorine (Solangi \& Iqbal 2011). According to Devine and Dikeman (2014), the presence of salts increases the solubility of myofibrillar proteins in meat since the salt is available rapidly within intracellular myofibrils where it will subsequently fragment to become smaller pieces. The myofibril protein controls the water-binding activity in the meat. In addition, the salts also assist the myofibres integration by swelling and myofibrillar proteins dissolutions; therefore, promotes better overall acceptance of the fat-replaced meatballs especially with the young coconuts.

Table 3 shows the Pearson correlation between all the analyses against the sensory parameters. Cooking yield and hardness of the meatballs exhibited high positive correlations $(p<0.05)$, while the fat content of the meatballs had high negative correlations $(p<0.05)$ against all the sensory parameters. The moisture content and springiness also had positive correlations $(p<0.05)$ against all the sensory parameters except for the colour and aroma, respectively. Gumminess and chewiness had positive correlations $(p<0.05)$ against all the sensory parameters except for the colour of the meatballs. In contrast, negative correlations $(p<0.05)$ were observed for the cohesiveness against all the sensory parameters of the meatballs. These results can be interpreted as the preference of the panellists against meatballs with high moisture, which directly related to the high cooking yield. The panellists also preferred meatballs that had lower fat content, which served the objective of this study. Meatballs with sufficient hardness but springy, gummy and chewy at the same time, which reflect the characteristics of the normal meatballs also were preferred by the panellist. Nevertheless, the colour of the meatballs did not affect $(p>0.05)$ the panellists' preference of the meatballs. 
TABLE 3. Correlations of analyses with sensory attributes of meatballs from different maturities and varieties using Pearson correlation (without control)

\begin{tabular}{|c|c|c|c|c|c|}
\hline & Sensory texture & Sensory colour & Sensory taste & Sensory aroma & $\begin{array}{c}\text { Sensory overall } \\
\text { acceptability }\end{array}$ \\
\hline Moisture & 0.499 & $0.150^{*}$ & 0.486 & 0.539 & 0.506 \\
\hline Protein & $-0.325^{*}$ & $-0.435^{*}$ & $-0.300 *$ & $-0.258 *$ & $-0.304 *$ \\
\hline Fat & -0.838 & -0.801 & -0.808 & -0.939 & -0.835 \\
\hline carbo & $-0.034 *$ & $0.333^{*}$ & $-0.045^{*}$ & $-0.020 *$ & $-0.048^{*}$ \\
\hline$L^{*}$ & $-0.071 *$ & $-0.311 *$ & $-0.092 *$ & $-0.190 *$ & $-0.087^{*}$ \\
\hline$a^{*}$ & $0.161 *$ & $0.268^{*}$ & $0.296^{*}$ & $-0.032 *$ & $0.223^{*}$ \\
\hline$b^{*}$ & $-0.181 *$ & $-0.247 *$ & $-0.118^{*}$ & $-0.293^{*}$ & $-0.150^{*}$ \\
\hline Cooking yield & 0.900 & 0.808 & 0.897 & 0.787 & 0.900 \\
\hline WHC & $-0.065^{*}$ & $-0.011 *$ & $0.044^{*}$ & $0.012 *$ & $0.001^{*}$ \\
\hline Springiness & 0.592 & 0.474 & 0.613 & $0.432 *$ & 0.600 \\
\hline Hardness & 0.680 & 0.533 & 0.695 & 0.586 & 0.687 \\
\hline Cohesiveness & -0.518 & -0.587 & -0.511 & -0.566 & -0.517 \\
\hline Gumminess & 0.574 & $0.399 *$ & 0.589 & $0.462 *$ & 0.580 \\
\hline Chewiness & 0.599 & $0.425^{*}$ & 0.614 & 0.476 & 0.605 \\
\hline
\end{tabular}

Correlation is significantly different $(\mathrm{p}<0.05)$ as measured by Pearson correlation and strong correlation is when $\mathrm{r}^{2}=1$. *not significant $(\mathrm{p}<0.05)$. WHC: water holding capacity

\section{CONCLUSION}

This study investigated the fat replacement in meatballs processing using coconut flesh from different maturity stages (young and mature) and coconut varieties (MAWA, MYD, and Pandan) as the fat replacers. The maturity and variety of the coconut flesh showed significant interaction effect towards most properties of the meatballs. The young coconuts were superior to the mature ones to be used as fat replacers which contributed to meatballs with better cooking yield, overall texture properties, and sensory properties. Among all the three varieties, the use of Pandan and MYD resulted in meatballs with better quality. Incorporation of young Pandan contributed to meatballs with high moisture, low fat and acceptable sensory properties. For the young MYD, even though the moisture content was not high, the meatballs had low fat content, high WHC and increased in redness which thus resulted in high sensory acceptance score for the colour property of the meatball. Meatballs with the young MYD also received the highest sensory acceptance scores in terms of taste, texture and overall acceptability. In conclusion, both young Pandan and young MYD bear great potential to be used as fat replacers in production of reduced-fat meatballs.

\section{ACKNOWLEDGEMENTS}

This work was supported by the Ministry of Higher Education under the Fundamental Research Grant Scheme (FRGS/1/2019/STG04/UPM/02/7) and the Faculty of Food Science and Technology, Universiti Putra Malaysia. 


\section{REFERENCES}

Akbari, M., Eskandari, M.H. \& Davoudi, Z. 2019. Application and functions of fat replacers in low-fat ice cream: A review. Trends in Food Science \& Technology 86: 34-40.

Alejandre, M., Astiasarán, I., Ansorena, D. \& Barbut, S. 2019. Using canola oil hydrogels and organogels to reduce saturated animal fat in meat batters. Food Research International 122: 129-136.

Appaiah, P., Sunil, L., Kumar P.P. \& Krishna, A.G. 2015. Physicochemical characteristics and stability aspects of coconut water and kernel at different stages of maturity. Journal of Food Science and Technology 52(8): 5196-5203.

Aslinah, L.N.F., Yusoff, M.M. \& Ismail-Fitry, M.R. 2018. Simultaneous use of adzuki beans (Vigna angularis) flour as meat extender and fat replacer in reduced-fat beef meatballs (bebola daging). Journal of Food Science and Technology 55(8): 3241-3248.

Association of Officiating Analytical Chemists. 2005. Official Method of Analysis. 8th ed. Washington, D.C.: Association of Officiating Analytical Chemists (AOAC).

Banon, S., Diaz, P., Nieto, G., Castillo, M. \& Alvarez, D. 2008. Modelling the yield and texture of comminuted pork products using color and temperature. Effect of fat/lean ratio and starch. Meat Science 80(3): 649-655.

Bhosale, S.S., Biswas, A.K., Sahoo, J., Chatli, M.K., Sharma, D.K. \& Sikka, S.S. 2011. Quality evaluation of functional chicken nuggets incorporated with ground carrot and mashed sweet potato. Food Science and Technology International 17(3): 233-239.

Chen, Y., She, Y., Zhang, R., Wang, J., Zhang, X. \& Gou, X. 2020. Use of starch-based fat replacers in foods as a strategy to reduce dietary intake of fat and risk of metabolic diseases. Food Science \& Nutrition 8(1): 16-22.

Chuntarat, S., Na Jom, K. \& Tongchitpakdee, S. 2013. Effect of maturity on quality and chemical composition of coconut kernel (Cocos nucifera). Acta Horticulturae 1088: 227-230.

Devine, C. \& Dikeman, M. 2014. Encyclopedia of Meat Sciences. New York: Academic Press.

Ergezer, H., Akcan, T. \& Serdaroglu, M. 2014. The effects of potato puree and bread crumbs on some quality characteristics of low-fat meatballs. Korean Journal for Food Science of Animal Resources 34(5): 561-569.

Fernandez-Gines, J.M., Fernandez-Lopez, J., Sayas-Barbera, E., Sendra, E. \& Perez-Alvarez, J.A. 2004. Lemon albedo as a new source of dietary fiber: Application to bologna sausages. Meat Science 67(1): 7-13.

Gok, V., Akkaya, L., Obuz, E. \& Bulut, S. 2011. Effect of ground poppy seed as a fat replacer on meat burgers. Meat Science 89(4): 400-404.

Grigelmo-Miguel, N., Gorinstein, S. \& Martín-Belloso, O. 1999. Characterisation of peach dietary fibre concentrate as a food ingredient. Food Chemistry 65(2): 175-181.
Guedes-Oliveira, J.M., Salgado, R.L., Costa-Lima, B.R., Guedes-Oliveira, J. \& Conte-Junior, C.A. 2016. Washed cashew apple fiber (Anacardium occidentale L.) as fat replacer in chicken patties. LWT-Food Science and Technology 71: 268-273.

Halim, H.H., Williams Dee, E., Pak Dek, M.S., Hamid, A.A., Ngalim, A., Saari, N. \& Jaafar, A.H. 2018. Ergogenic attributes of young and mature coconut (Cocos nucifera L.) water based on physical properties, sugars and electrolytes contents. International Journal of Food Properties 21: 2378-2389.

Huang, S.C., Shiau, C.Y., Liu, T.E., Chu, C.L. \& Hwang, D.F. 2005. Effects of rice bran on sensory and physico-chemical properties of emulsified pork meatballs. Meat Science 70(4): 613-619.

Huda, N., Shen, Y.H., Huey, Y.L., Ahmad, R. \& Mardiah, A. 2010. Malaysian commercial beef meatballs. American Journal of Food Technology 5(1): 13-21.

Hughes, E., Mullen, A.M. \& Troy, D.J. 1998. Effects of fat level, tapioca starch and whey protein on frankfurters formulated with $5 \%$ and $12 \%$ fat. Meat Science 48(1-2): 169-180.

Ikhlas, B., Huda, N. \& Noryati, I. 2011. Chemical composition and physicochemical properties of meatballs prepared from mechanically deboned quail meat using various types of flour. International Journal of Poultry Science 10(1): 30-37.

Imo, C., Ezeonu, C.S., Imo, N.G. \& Anigbo, C.J. 2018. Proximate, mineral and phytochemical composition of Cocos nucifera nut. Asian Journal of Biochemistry 13: 9-14.

Jalal, H., Mir, S., Wani, S.A., Sofi, A.H., Pal, M.A. \& Rather, F. 2013. Development of low-fat meat products. International Journal of Food Nutrition and Safety 4(3): 98-107.

Jangchud, K., Puchakawimol, P. \& Jangchud, A. 2007. Quality changes of burnt aromatic coconut during 28-day storage in different packages. LWT-Food Science and Technology 40(7): 1232-1239.

Kahar, S.N.S., Ismail-Fitry, M.R., Yusoff, M.M., Rozzamri, A., Bakar, J. \& Ibadullah, W.Z.W. 2021. Substitution of fat with various types of squashes and gourds from the Cucurbitaceae family in the production of low-fat buffalo meat patties. Malaysian Applied Biology 50(1): 169-179.

Kim, S.H. \& Chin, K.B. 2007. Physico-chemical properties and changes of sarcoplasmic protein bands of chicken meat cuts with or without salt during cooking temperatures. Journal of Animal Science and Technology 49(2): 269-278.

Luckose, F. \& Pandey, M.C. 2014. Combined effect of nonmeat proteins and different binders on low salt poultry meat systems. International Journal of Advanced Research 2(11): 413-424.

Mohamad Ja, S.M., Khalid, R.M. \& Othaman, R. 2019. Coconut oil based microemulsion formulations for hair care product application. Sains Malaysiana 48(3): 599605 . 
Niu, Y., Fang, H., Huo, T., Sun, X., Gong, Q. \& Yu, L. 2020. A novel fat replacer composed by gelatin and soluble dietary fibers from black bean coats with its application in meatballs. LWT - Food Science and Technology 122: 109000 .

Nnorom, I.C., Nnadozie, C., Ugwa, R. \& Obike, A.I. 2013. Proximate and trace metal analysis of coconut (Cocos nucifera) collected from Southeastern, Nigeria. ABSU Journal of Environment, Science and Technology 3: 357361.

Onsaard, E., Vittayanont, M., Srigam, S. \& Mc Clements, D.J. 2006. Comparison of properties of oil-in-water emulsions stabilized by coconut cream proteins with those stabilized by whey protein isolate. Food Research International 39(1): 78-86.

Ozturk, B. \& Serdaroglu, M. 2018. Effects of Jerusalem artichoke powder and sodium carbonate as phosphate replacers on the quality characteristics of emulsified chicken meatballs. Korean Journal for Food Science of Animal Resources 38(1): 26-42.

Pietrasik, Z. \& Shand, P.J. 2003. The effect of quantity and timing of brine addition on water binding and textural characteristics of cooked beef rolls. Meat Science 65(2): 771-778.

Savva, S.C. \& Kafatos, A. 2015. Vegetable oils: dietary importance. In Encyclopedia of Food and Health, edited by Caballero, B., Finglas, P.M. \& Toldrá, F. Philadelphia: Elsevier. pp. 365-372.

Serdaroglu, M. 2006. Improving low fat meatball characteristics by adding whey powder. Meat Science 72(1): 155-163.

Serdaroglu, M. \& Degirmencioglu, O. 2004. Effects of fat level $(5 \%, 10 \%, 20 \%)$ and corn flour $(0 \%, 2 \%, 4 \%)$ on some properties of Turkish type meatballs (koefte). Meat Science 68(2): 291-296.

Serdaroglu, M., Yildiz-Turp, G. \& Abrodímov, K. 2005. Quality of low-fat meatballs containing legume flours as extenders. Meat Science 70(1): 99-105.

Skipnes, D., Ostby, M.L. \& Hendrickx, M.E. 2007. A method for characterising cook loss and water holding capacity in heat treated cod (Gadus morhua) muscle. Journal of Food Engineering 80(4): 1078-1085.
Solangi, A.H. \& Iqbal, M.Z. 2011. Chemical composition of meat (kernel) and nut water of major coconut (Cocos nucifera L.) cultivars at coastal area of Pakistan. Pakistan Journal of Botany 43(1): 357-363.

Terdwongworakul, A., Chaiyapong, S., Jarimopas, B. \& Meeklangsaen, W. 2009. Physical properties of fresh young Thai coconut for maturity sorting. Biosystems Engineering 103(2): 208-216.

Trinidad, T.P., Mallillin, A.C., Valdez, D.H., Loyola, A.S., Askali-Mercado, F.C., Castillo, J.C., Encabo, R.R., Masa, D.B., Maglaya, A.S. \& Chua, M.T. 2006. Dietary fiber from coconut flour: A functional food. Innovative Food Science \& Emerging Technologies 7(4): 309-317.

Yilmaz, I. 2004. Effects of rye bran addition on fatty acid composition and quality characteristics of low-fat meatballs. Meat Science 67(2): 245-249.

Yilmaz, I. \& Dağlığlu, O. 2003. The effect of replacing fat with oat bran on fatty acid composition and physicochemical properties of meatballs. Meat Science 65(2): 819-823.

Siti Khadijah Khalid, Mohammad Rashedi Ismail-Fitry*, Masni Mat Yusoff \& Nur Izzah Arifah Zarul Anuar

Department of Food Technology

Faculty of Food Science and Technology

Universiti Putra Malaysia

43400 UPM Serdang, Selangor Darul Ehsan

Malaysia

Hani Hafeeza Halim \& Ahmad Haniff Jaafar

Department of Food Science

Faculty of Food Science and Technology

Universiti Putra Malaysia

43400 UPM Serdang, Selangor Darul Ehsan

Malaysia

*Corresponding author; email: ismailfitry@upm.edu.my

Received: 25 March 2020

Accepted: 20 December 2020 